\title{
PENGEMBANGAN MODEL PEMBELAJARAN KOOPERATIF TIPE BERBAGI DENGAN ASESMEN PROYEK UNTUK SISWA SMK KELAS XI SEMESTER I KOMPETENSI KEAHLIAN TEKNIK PEMESINAN DI SMK NEGERI 3 SINGARAJA
}

\author{
Ketut Subudi, I Made Candiasa, I Gusti Lanang Agung Parwata \\ Program Studi Penelitian Dan Evaluasi Pendidikan, Program Pascasarjana \\ Universitas Pendidikan Ganesha \\ Singaraja, Indonesia \\ e-mail: (ketut.subudi1, made.candiasa, agung.parwata)@undiksha.ac.id
}

\begin{abstract}
Abstrak
Penelitian ini bertujuan untuk mengembangkan model pembelajaran kooperatif tipe berbagi dengan asesmen proyek untuk kompetensi keahlian teknik pemesinan di SMK Negeri 3 Singaraja. Penelitian ini merupakan penelitian pengembangan dengan model Borg \& Gall yang terdiri dari tujuh langkah yaitu: 1) penelitian dan pengumpulan data awal, 2) perencanaan, 3) pembuatan produk awal, 4) uji coba awal, 5) perbaikan produk awal, 6) uji coba lapangan, dan 7) perbaikan produk operasional. Hasil penelitian yang diperoleh adalah model pembelajaran yang terdiri dari: 1) sintak model pembelajaran kooperatif tipe berbagi adalah: penyampaian tujuan dan persiapan, menyajikan informasi, mengorganisir siswa dalam tim belajar, diskusi dalam tim memecahkan masalah yang dihadapi, penyampaian hasil, menarik kesimpulan, melakukan evaluasi, dan memberikan pengakuan dan penghargaan. 2) sistem sosial berupa pembelajaran berkelompok terjadi transfer ilmu melalui interaksi antar anggota kelompok dalam pembelajaran, 3) prinsip reaksi siswa berperan aktif dalam pembelajaran, guru sebagai fasilitator dan moderator, 4) sistem pendukung dan dampak instruksional dalam model pembelajaran adalah adanya rencana pelaksanaan pembelajaran dan perangkat asesmen proyek, serta peningkatan proses dan aktivitas siswa dalam pembelajaran dan penguasaan kompetensi mata pelajaran. Hasil uji validitas isi dengan menggunakan formula gregory diperoleh validitas buku model pembelajaran sebesar 1.00 dengan kategori sangat tinggi, validitas RPP sebesar 1.00 dengan kategori sangat tinggi dan perangkat asesmen proyek sebesar 1.00 dengan kategori sangat tinggi. Uji coba penilaian kepraktisan dari guru dan siswa sebagai pengguna model telah memenuhi kriteria praktis.
\end{abstract}

Kata kunci: asesmen proyek, kooperatif tipe berbagi.

\begin{abstract}
This research aimed at developing sharing type of cooperative learning model with project assessment for machining techniques of skills competency at SMK Negeri 3 Singaraja. This research was a Borg and Gall research and development model that consists of seven steps which are: 1) pre research and data collection, 2) planning, 3) pre product making, 4) initial test, 5) early product improvements, 6) field trials, and 7) improvement of operational product. The results of the research was a learning model that consists of: 1) the syntaxes of sharing type of cooperative learning model are informing the goals and preparation, presentations, students organizing, team discussion, results presentations, concluding, evaluation, and feedback, 2) social system in form of group learning occurs knowledge transfer through interactions of group members in learning process, 3) principles of students reaction play an active role in learning, teacher as a facilitators and moderators, 4) supporting systems and instructional impact in learning model are the existence of the implementation plan of learning and project assessment instruments, and improvement of students process and activity in learning and mastery of subject competencies. Content validity test of Gregory formula shows 1.00 in validity of learning model book at very high category, 1.00 in validity of the implementation plan of learning at very high category and 1.00 of project assessments instruments at very high category. Practicality assessment trials from teacher and students as the users of the model has met the practical criteria.
\end{abstract}

Keywords: project assessment, sharing type of cooperative learning. 


\section{PENDAHULUAN}

Salah satu kunci keberhasilan suatu pembangunan di negara-negara maju adalah tersedianya penduduk yang terdidik dalam jumlah, jenis dan tingkat yang memadai. Pendidikan mempunyai peranan penting dalam proses pembangunan bangsa sehingga tidak bisa di pungkiri bahwa pembangunan pendidikan perlu diprioritaskan dalam pembangunan nasional.

Dalam undang-undang Republik Indonesia Nomor 20 Tahun 2003 tentang Sistem Pendidikan Nasional, pada pasal 3 ditegaskan bahwa pendidikan nasional "berfungsi mengembangkan kemampuan dan membentuk watak serta peradaban bangsa yang bermartabat dalam rangka mencerdaskan kehidupan bangsa, bertujuan untuk berkembangnya potensi peserta didik agar menjadi manusia yang beriman dan bertakwa kepada Tuhan Yang Maha esa, berakhlak mulia, sehat berilmu, cakap, kreatif, mandiri dan menjadi Warga Negara yang demokratis serta bertanggungjawab".

Lulusan SMK diharapkan mampu menciptakan peluang kerja sendiri atau paling tidak siap terjun ke dunia kerja. Dalam upaya optimalisasi kompetensi lulusan, penentuan model pembelajaran yang tepat sangat penting. Model pembelajaran yang diterapkan pada pembelajaran harus relevan dengan proses pembelajaran di SMK. Pendidikan kejuruan memiliki karakteristik yang berbeda dengan pendidikan umum. Dalam pendidikan kejuruan proses dan hasil pembelajaran lebih cenderung dalam bentuk kompetensi. Kompetensi adalah atribut individu peserta didik, sehingga asesmen berbasis kompetensi bersifat individual. Kompetensi siswa didefinisikan sebagai pengetahuan, keterampilan dan nilai-nilai, serta pola pikir dan bertindak sebagai refleksi dari pemahaman dan penghayatan dari pengalaman belajar siswa. Pengembangan pengalaman belajar diarahkan untuk mengakomodasi aspek kompetensi dan kecakapan hidup (life skill). Pembelajaran pendidikan kejuruan merupakan pembelajaran yang sarat dengan keterampilan psikomotorik. Aspek psikomotorik atau keterampilan dapat diketahui dengan cara peserta didik diminta untuk mendemonstrasikan kemampuan dan keterampilannya.

Permasalahan yang sering muncul dalam proses pembelajaran adalah: (1) interaksi siswa dan guru kurang maksimal, (2) peran aktif siswa tidak maksimal, (3) kesempatan siswa untuk mencoba kurang, (4) bobot keterampilan masih kurang, (5) kesulitan dalam memadukan pembelajaran teori dan praktek, dan (6) sulit memadukan pendidikan karakter dalam pembelajaran. Keterampilan guru dalam rangka mendesain, mengembangkan dan mengimplementasikan asesmen dalam pembelajaran yang dapat meningkatkan praktik pembelajaran juga masih kurang memadai.

Memperhatikan masalah di atas, perlu dikembangkan model pembelajaran yang mampu menjadikan proses belajar lebih bermakna, meningkatkan peran siswa melalui interaksi, mengembangkan pengalaman belajar yang dapat mengakomodasi pencapaian kompetensi dan kecakapan hidup. Joyce, Weil, \& Calhoun, (2009) mendefinisikan model pembelajaran merupakan deskripsi dari lingkungan belajar, termasuk perilaku kita sebagai guru saat model pembelajaran tersebut digunakan. Model-model pembelajaran memiliki berbagai macam fungsi yaitu sebagai perencanaan pembelajaran dan kurikulum untuk merancang materi-materi pembelajaran termasuk multimedia.

Joyce, Weil, dan Shower, (1992: 1316) menyatakan, suatu model pembelajaran dapat dianalisis sesuai dengan empat konsep inti operasional model yang mencirikan, yaitu: (1) sintak (urutan aktivitas mengajar dan belajar), (2) sistem sosial (peran dan hubungan siswa dan guru), (3) prinsip reaksi (cara guru memandang dan merespons siswa terhadap apa yang dilakukan), dan (4) sistem pendukung (persyaratan dan dukungan apa yang 
diperlukan). Selain konsep inti operasional model ada komponen lain, yaitu: (5) tujuan dan asumsi, dan (6) dampak pembelajaran dan dampak pengiring pembelajaran.

Model pembelajaran kooperatif memiliki potensi yang besar dalam upaya mengakomodasi aspek kompetensi dan kecakapan hidup terutama aspek akademis dan sosial siswa. Joyce \& Weil, (2009) menjelaskan bahwa model-model mengajar sesungguhnya merupakan model-model belajar. Sebagaimana kita membantu siswa memperoleh informasi, ide, keterampilan, nilai, cara berpikir, dan makna dari mengekspresikan diri, kita juga mengajar siswa tentang bagaimana cara belajar. Pada kenyataannya, yang paling penting dari hasil pembelajaran jangka panjang adalah kemampuan siswa untuk belajar secara lebih mudah dan efektif di masa yang akan datang.

Model pembelajaran kooperatif tidak sama dengan sekedar belajar dalam kelompok. Terdapat unsur-unsur yang membedakan model pembelajaran kooperatif dengan pembagian kelompok biasa yang dilakukan tanpa pertimbangan. Pelaksanaan prosedur pembelajaran kooperatif dengan benar akan memungkinkan pendidik mengelola kelas dengan lebih baik dan efektif. Slavin (dalam Isjoni, 2009:15) menyatakan pembelajaran kooperatif adalah suatu model pembelajaran dimana siswa belajar dan bekerja dalam kelompok-kelompok kecil secara kolaboratif yang anggotanya 5 orang dengan struktur kelompok heterogen. Terdapat lima unsur dalam pembelajaran kooperatif menurut Johnson (dalam Anita Lie, 2007:30) yaitu; saling ketergantungan positif, tanggung jawab perseorangan, tatap muka, komunikasi antar anggota, dan evaluasi proses kelompok.

Pembelajaran produktif pada SMK dengan model pembelajaran kooperatif dengan penilaian proyek cocok diterapkan pada proses pembelajaran. Proyek atau produk yang dibuat disesuaikan dengan kompetensi dasar dan indikator pada silabus. Penerapan pembelajaran kooperatif dilakukan dengan membentuk kelompok-kelompok siswa yang berjumlah
4-5 orang dengan kemampuan heterogen. Pembagian heterogen diharapkan terjadi transfer ilmu dari siswa dengan kemampuan lebih kepada siswa yang memiliki kemampuan kurang dalam kelompok. Interaksi siswa dalam kelompok memungkinkan siswa lebih mudah memahami konsep-konsep sulit melalui diskusi bersama kelompok memecahkan masalah yang dihadapi.

Penelitian ini adalah penelitian pengembangan model pembelajaran kooperatif tipe berbagi dengan asesmen proyek mengadopsi sistem pembelajaran pada subak di Bali. Subak merupakan sistem irigasi yang ada di Bali, sebagai sistem swadaya masyarakat yang berfungsi mengatur pembagian aliran irigasi yang mengairi setiap petak areal persawahan. Sistem ini dikelola secara berkelompok dan bertingkat disertai pembagian peran yang spesifik bagi setiap anggotanya. Dirjen Pembangunan dan Pemberdayaan Masyarakat Desa (2015) menyatakan subak sebagai sistem irigasi yang di dalamnya menyangkut masyarakat hukum adat yang memiliki karakteristik sosio-agraris-religius, dan merupakan perkumpulan petani yang mengelola air irigasi di lahan sawah. Rasa kebersamaan dalam mengupayakan kelestarian sumber daya alam serta upaya peningkatan produksi pertanian tampak pada organisasi subak. Semua anggota memikul tanggung jawab tersebut bersama-sama berdasarkan semangat gotong royong. Semua anggota mengambil peran dalam segala aktivitas organisasi sesuai dengan keahlian dan keterampilan masing-masing.

Pusposutarjo dan Wardhana (dalam Windia, 2010) menyebutkan bahwa kekuatan dari sistem irigasi yang berwatak sosio-kultural yakni: (i) kemampuannya untuk mengabsorbsi perkembangan teknologi yang berkembang disekitarnya; (ii) kemampuannya untuk berdaptasi dengan dinamika budaya sekitarnya; (iii) kemampuannya untuk bersifat good governance; dan (iv) kemampuannya dalam menata organisasinya yang bersfat fleksibel, yang disesuaikan dengan kondisi lingkungan strategisnya.Sistem pendidikan 
yang ada dalam organisasi subak menjadikan subak mampu selaras dengan perkembangan teknologi dan kondisi lingkungan. Selain itu, kepentingan bersama yang terjadi dalam subak berhasil menjaga persatuan dan kesatuan.

Windia (2010) menyebut bahwa keseluruhan kearifan lokal yang termasuk dalam organisasi subak secara kategorikal terdiri atas: kearifan religius, kultural, ekologis, institusional, ekonomi, teknologis, hukum, dan keamanan. Kearifan religius fokus pada ketuhanan dan spiritual. Sementara itu, kearifan kultural fokus pada energi budaya yang mencakup etika, logika, estetika, dan praktika. Kearifan ekologis fokus pada konservasi, keseimbangan, dan sustainabilitas lingkungan. Kearifan institusional fokus pada integritas organisasi. Kearifan ekonomis fokus pada usaha yang bersifat kreatif dan produktif. Kearifan hukum fokus pada aspek legalitas dengan memberi penghargaan pada pihak yang berprestasi dan memberi hukuman kepada pihak yang bersalah demi ketertiban dan keadilan. Kearifan teknologis fokus pada kemampuan teknologi dan kemampuan pengetahuan tradisonal petani untuk memecahkan masalah-masalah pertanian. Kearifan keamanan fokus pada upaya pengamanan hasil pertanian dan wilayah pertanian.

Konsep berbagi dalam model pembelajaran sistem subak berbasis budaya lokal, sudah terbukti mampu mewariskan kompetensi di bidang keterampilan dari satu generasi ke generasi berikutnya. Nilai-nilai yang terkandung dalam filosofi subak di aplikasikan dalam model pembelajaran. Peran aktif siswa, rasa tanggungjawab yang sama, adil dan merata, tanpa ada siswa yang menonjol/mendominasi kegiatan belajar dalam kelompok yang terkandung dalam filosofi subak yang diadopsi dalam pembelajaran kooperatif tipe berbagi. Model pembelajaran kooperatif dengan strategi berbagi yang diadopsi dari sitem kerja subak menghasilkan model pembelajaran baru yang akan diterapkan. Pembelajaran berbasis budaya diharapkan mampu mengoptimalkan pewarisan nilai-nilai budaya pada generasi muda dan mengintegrasikannya dalam kehidupan. Penerapan pendekatan budaya dalam pembelajaran menjadikan pembelajaran lebih bermakna, lebih kontekstual yang mampu menumbuhkan motivasi belajar, serta melestarikan budaya. Pembelajaran berbasis budaya diharapkan dapat menghasilkan kompetensi dalam satu kesatuan teori dan praktek. Kompetensi tersebut diharapkan muncul dalam pola pikir, sikap dan perilaku di masyarakat dan terwariskan secara kontinyu dari generasi ke generasi. Pembelajaran berbasis budaya diharapkan terjadi dalam kolaborasi yang mengedepankan interaksi sosial. Nilai-nilai luhur untuk kebersamaan, simpati dan empati juga diharapkan tumbuh dari interaksi sosial. Pembentukan pengetahuan siswa dapat berjalan selaras jika materi pelajaran sesuai dengan latar belakang budaya yang dimiliki siswa.

Model pembelajaran kooperatif tipe berbagi yang dikembangkan dengan asesmen bentuk proyek sangat cocok diterapkan pada sekolah kejuruan. Kegiatan praktik dengan pemberian tugas berupa job atau proyek pada siswa memberikan kesempatan kepada siswa untuk menerapkan sikap, pengetahuan dan keterampilan yang sudah dimilikinya. Dalam kegiatan pembelajaran kesulitan yang dirasakan siswa dalam pembelajaran teori dapat dimengerti ketika diaplikasikan melalui eksperimen ataupun praktik, sehingga metode ekperimen atau praktik hendaknya mampu memberikan jawaban melalui proses yang logis. Proses tersebut dalam pendekatan scientifik meliputi: 1) melakukan pengamatan setiap tahapan, 2) melakukan praktik sesuai dengan unjuk kerja 3) mengumpulkan data yang dihasilkan setiap tahapan 4) menganalisa hasil data menggunakan analisa diskriptif, 5) mengasosiasikan beberapa pengethuan dalam uraian materi pembelajaran untuk membentuk suatu kesimpulan 6) mengkomunikasikan hasil yang dicapai apakah sesuai dengan kriteria yang 
ditetapkan dan membuat laporan. Asesmen proyek dalam pembelajaran Teknik Pemesinan Frais dilaksanakan mulai dari persiapan kerja, proses (sistematika dan cara kerja), dan kegiatan penilaian hasil kerja, pelaporan sebagai tahap penilaian hasil kerja. Ketiga proses penilaian tersebut disajikan dalam lembar penilaian asesmen proyek.

Tujuan pengembangan model pembelajaran kooperatif tipe berbagi dengan asesmen proyek ini untuk: (1) merumuskan sintak, sistem sosial, prinsip reaksi, sistem pendukung dan dampak instruksional model pembelajaran kooperatif tipe berbagi dengan asesmen proyek., (2) mengetahui kepraktisan model pembelajaran kooperatif tipe berbagi dengan asesmen proyek dalam pembelajaran Teknik Pemesinan Frais.

\section{METODE PENELITIAN}

Penelitian ini merupakan penelitian pengembangan dengan desain model pengembangan Borg \& Gall yang terdiri dari sepuluh tahapan, namun dalam penelitian ini tahapan yang dilaksanakan hanya sampai pada tahap ke tujuh terdiri dari: 1) penelitian dan pengumpulan data awal, (2) perencanaan, (3) pembuatan produk awal, (4) uji coba awal, (5) perbaikan produk awal, (6) uji coba lapangan, dan (7) perbaikan produk operasional. Pengembangan model pembelajaran kooperatif tipe berbagi dengan asesmen bentuk proyek ini diperuntukkan pada siswa kelas XI semester I kompetensi keahlian Teknik Pemesinan. Hasil pengembangan model pembelajaran dalam penelitian ini di uji tingkat validitas dan kepraktisannya tanpa dilakukan uji keefektifan mengingat keterbatasan biaya dan juga waktu.

Tingkat validitas dari model pembelajaran yang dikembangkan diketahui melalui uji ahli dengan analisis data menggunakan formula Gregory dan tingkat kepraktisan model di dapatkan dari hasil analisis data angket kepraktisan guru dengan analisis mengacu pada kategori penilaian dari Saifuddin Azwar (2010:163), dan penilaian angket respon siswa di analisis dengan menghitung persentase jawaban ya atau tidak dibagi jumlah responden. Subyek dalam penelitian ini adalah 30 orang siswa kelas XI kompetensi keahlian Teknik Pemesinan dan satu orang guru pengajar pada kompetensi keahlian Teknik Pemesinan. Uji coba pada penelitian ini hanya dilakukan pada kelas kecil dan tidak sampai pada tahap eksperimen mengingat waktu dan keterbatasan peneliti.

\section{HASIL PENELITIAN DAN PEMBAHASAN}

Hasil pengembangan dari penelitian ini adalah model pembelajaran kooperatif tipe berbagi dengan asesmen proyek. Sesuai dengan tahapan pengembangan Borg \& Gall maka tahapan pengembangan model pada penelitian ini terdiri atas 7 tahapan yang meliputi : (1) penelitian dan pengumpulan data awal, dimulai dari mengidentifikasi perkiraan kebutuhan awal dan studi literatur. Hasil yang didapatkan adalah adanya keterbatasan sarana dalam proses belajar khususnya pada pembelajaran praktik, terbatasnya jumlah jam pelajaran, siswa lebih termotivasi dalam proses belajar pada saat kegiatan praktik di bengkel, dan kemampuan siswa khususnya pada kompetensi keahlian Teknik Pemesinan kurang (2) perencanaan, merumuskan tujuan dan indikator yang ada dalam silabus merupakan kegiatan yang dilaksanakan pada tahap ini, (3) pembuatan produk awal, model pembelajaran kooperatif tipe berbagi dengan asesmen proyek beserta perangkat pendukungnya berupa buku model, RPP, dan perangakat asesmen proyek, instrumen penilaian kualitas berupa instrumen kevalidan dan kepraktisan,(4) uji coba awal, dengan validasi oleh 2 orang judges/ahli dengan hasil yang didapat yaitu adanya revisi pada Instrumen RPP dan angket penilaian respon siswa terhadap penerapan model pembelajaran, (5) perbaikan produk awal, hasil revisi instrumen validasi RPP dan angket penilaian respon siswa selanjutnya divalidasi kembali oleh ahli, (6) uji coba lapangan, penerapan model pembelajaran yang dikembangkan pada siswa kelas XI TPm1 pada mata pelajaran Teknik Pemesinan Frais sebanyak 3 kali 
pertemuan.Penerapan model pembelajaran ini dilakukan hanya sebatas uji coba dan tidak sampai pada eksperimen, dan (7) perbaikan produk operasional, pada tahap ini tidak diperlukan adanya perbaikan pada produk pengembangan.

Hasil penelitian tentang komponenkomponen pembelajaran yang didapatkan adalah: sintak, yang terdiri dari langkah 1 Penyampaian Tujuan dan Persiapan diawali dengan melakukan absensi/mengecek kehadiran siswa, menyampaikan tujuan pembelajaran yang ingin dicapai sesuai tujuan dan Indikator Pencapaian Kompetensi (IPK) mata pelajaran Teknik Pemesinan Frais yang ada pada RPP, dan memberikan motivasi kepada siswa untuk siap belajar dan menyiapkan peralatan praktik teknik pemesinan frais. Selama 3 kali pertemuan, hasil uji coba model pembelajaran yang dikembangkan didapatkan bahwa pada tahap penyampaian tujuan dan persiapan dapat terlaksana pada keseluruhan pertemuan. Berdasarkan hasil observasi keterlaksanaan didapatkan persentase keterlaksanaan pada tahap ini mencapai angka $100 \%$ Langkah 2 Menyajikan Informasi, guru menjelaskan materi pemilihan pisau frais sesuai jenis pekerjaan, menjelaskan cara pemasangan pisau sesuai jenis pekerjaan, pemasangan ragum dan pemasangan benda kerja, menghitung parameter pemotongan, dan melakukan praktik mengefrais rata, sejajar, dan siku. Hasil observasi selama 3 kali pertemuan menunjukkan bahwa semua keterlaksanaan tahap penyampaian informasi dapat tercapai $100 \%$ pada semua pertemuan. Langkah 3 Mengorganisir Siswa dalam Tim Belajar guru membagi siswa kedalam 7 kelompok belajar dengan pembagian lima kelompok terdiri dari 4 orang siswa dan dua kelompok lainnya terdiri dari 5 orang siswa. Pembagian kelompok dilakukan secara heterogen tanpa melihat persamaan suku, agama dan setiap kelompok terdapat ketua kelompok. Guru membagi kelompok secara adil dan merata berdasarkan kemampuan yang dimiliki. Siswa membagi diri dalam kelompok yang sudah ditentukan
Persentase keterlaksanaan untuk tahap mengorganisir siswa ke dalam kelompok belajar selama 3 kali pertemuan adalah 100 $\%$ Langkah 4 Diskusi dalam Tim Memecahkan Masalah yang Dihadapi guru membimbing siswa ke dalam kelompok belajar yang sudah dibentuk untuk menyelesaikan pembuatan balok rumah pahat. Secara aktif siswa berbagi informasi dan pengetahuan melalui interaksi bersama kelompok. Konsep berbagi pada subak diawali dengan diskusi memecahkan masalah yang dihadapi dengan tugas dan tanggungjawab yang sama, adil dan merata. Siswa berbagi pengetahuan dari siswa yang lebih mampu kepada siswa dengan kemampuan kurang. Penerapan asesmen proyek pada tahap persiapan dan perencanaan siswa bersama anggota kelompok membuat WP menyiapkan peralatan dan bahan sesuai jobsheet, melakukan perhitungan parameter pemotongan. Tahap asesmen proyek berikutnya pada proses kerja siswa membagi tugas membersihkan dan mengkondisikan mesin untuk siap dipakai, memilih dan memasang piasu frais, memasang ragum, benda kerja, seting mesin dan melakukan pada 6 bidang sesuai dengan gambar kerja, serta melakukan pengukuran/pemeriksaan benda hasil praktik. Tahap akhir dari penilaian proyek adalah penilaian hasil kerja. Hasil dari pekerjaan siswa bersama kelompok dinilai berdasarkan rubrik penilaian yang sudah disediakan. Selain penilaian secara kelompok pada ranah keterampilan, pada tahap ini juga dilakukan penilaian secara individu untuk ranah pengetahuan, dan dilanjutkan dengan pembuatan laporan hasil pembelajaran sebagai akhir dari asesmen proyek.. Semua hasil dari penilaian yang didapatkan siswa adalah merupakan hasil bersama anggota kelompok yang dilakukan secara obyektif (tanpa membedakan siswa dengan kemampuan tinggi atau rendah). Pada pertemuan 1 keterlaksanaan tahap diskusi dalam tim memecahkan masalah yang dihadapi hanya sebesar $50 \%$. Hal ini disebabkan siswa masih merasa belum terbiasa atau belum bisa beradaptasi 
dengan kelompoknya. Penyebab lainnya bahwa mata pelajaran ini merupakan mata pelajaran yang baru didapatkan siswa sehingga siswa masih merasa awam dengan materi pemesinan frais. Namun pada pertemuan berikutnya persentase keterlaksanaan diskusi dalam tim memecahkan masalah yang dihadapi sudah dapat terlaksana dengan baik ditunjukkan dengan nilai $100 \%$. Langkah 5 Penyampaian Hasil, Menarik Kesimpulan, dan Melakukan Evaluasi. Pada langkah ini Guru membimbing siswa dalam mempresentasikan hasil praktik dari kerja kelompok. Hasil kegiatan belajar siswa bersama kelompok digabungkan dengan hasil penilaian individu sebagai bahan kajian dalam pengambilan keputusan hasil belajar siswa apakah sudah kompeten atau belum. Dari hasil ini dapat disimpulkan sebagai hasil akhir proses belajar, sebagai bahan kajian dalam melakukan evaluasi untuk pembelajaran berikutnya. Persentase keterlaksanaan penyampaian hasil pada pertemuan 1 hanya sebesar $67 \%$. Hal tersebut disebabkan karena siswa belum terbiasa bekerja menggunakan mesin frais, sehingga hasil yang didapatkan belum maksimal. Keterlaksanaan pada pertemuan 1 di evaluasi untuk mendapatkan hasil yang lebih baik. Pertemuan 2 dan 3 persentase keterlaksanaan penyampaian hasil, menarik kesimpulan dan melakukan evaluasi bisa tercapai $100 \%$. Siswa sudah lebih berhati hati dalam bekerja bersama kelompok menyelesaikan benda kerja. Langkah 6 Memberikan Pengakuan dan Penghargaan guru memberikan hasil penilaian akhir yang sudah didapatkan oleh kelompok memberikan keputusan hasil belajar apakah kompeten atau belum kompeten. Persentase keterlaksanaan pada tahap ini sebesar $100 \%$ pada semua pertemuan.

Sistem sosial pada pembelajaran kooperatif tipe berbagi ini mencakup hubungan siswa dan guru dan siswa dengan siswa lainnya dalam kelompok. Sistem sosial pada tahap penyampaian tujuan dan persiapan siswa diberikan pengarahan tujuan belajar siswa sebagai individu dan anggota kelompok, menjelaskan job yang harus diselesaikan.
Siswa bersama anggota kelompok mendiskusikan gambar kerja yang sudah diberikan. Pengetahuan siswa dalam membaca gambar kerja sangat diperlukan pada kegiatan ini. Siswa yang sudah memahami gambar kerja bisa berbagi pengetahuan kepada anggota kelompok lainnya. Tahap penyajian informasi guru menjelaskan materi penunjang kegiatan belajar mulai dari pemilihan peralatan mesin, pisau, pemasangan ragum dan benda kerja dan melakukan pengefraisan benda kerja. Siswa sudah mampu berperan dalam memilih macam-macam pisau frais sesuai jenis pekerjaan, pemasangan pisau frais bersama kelompok, siswa yang lebih mampu dapat membimbing siswa lain dalam kelompoknya. Fase mengorganisir siswa dalam tim guru berperan sebagai fasilitator dan membimbing kelompok yang masih mengalami kesulitan belajar. Siswa memecahkan masalah yang ditemukan pada fase diskusi tim. Fase penyampaian hasil, menarik kesimpulan, melakukan evaluasi, siswa bersama kelompok melakukan pengukuran benda kerja sesuai dengan kriteria penilaian. Peran aktif siswa sebagai anggota kelompok sama yaitu berperan aktif dengan tanggungjawab yang sama. Hasil pekerjaan yang belum sesuai akan diulang kembali bersama anggota kelompok. Secara umum semua kegiatan pembelajaran dilakukan siswa bersamasama dengan anggota kelompok dengan peran yang sama, tugas dan tanggungjawab yang sama secara adil. Keterlaksanaan sistem sosial pada pertemuan 1 sebesar $71,4 \%$ sedangkan pada pertemuan 2 dan 3 meningkat menjadi $100 \%$.

Prinsip reaksi, berkaitan dengan peran guru dalam pembelajaran. Siswa berperan aktif dalam pembelajaran kelompok yang ditunjukkan dengan adanya interaksi siswa dalam kelompok, guru membimbing kegiatan belajar siswa bersama kelompok. Masalah yang dihadapi siswa dalam pelaksanaan kegiatan praktik sangat beragam mulai dari pemasangan pisau frais pada mesin, memasang ragum, benda kerja, dan mengecek kerataan posisi benda kerja pada ragum. Kesulitan yang 
dialami siswa bersama kelompok diakibatkan karena kegiatan praktik ini sebagai pengalaman pertama dalam praktik pemesinan sehingga siswa masih belum terbiasa dalam mengoperasikan mesin. Peranan guru pada pertemuan awal menjadi sangat penting bagi kelompokkelompok belajar dengan memberikan contoh pemasangan dan pengoperasian mesin melalui simulasi dengan tujuan

\begin{tabular}{lll}
\hline No & \multicolumn{1}{c}{ Instrumen } & \multicolumn{1}{c}{ Penilaian } \\
\hline 1 & PFV Buku Model & Layak digunakan \\
2 & PFV RPP & $\begin{array}{l}\text { Layak dengan } \\
\text { Revisi } \\
\text { Layak digunakan }\end{array}$ \\
3 & $\begin{array}{l}\text { PFV Asesmen } \\
\text { Proyek }\end{array}$ & Layak digunakan \\
4 & $\begin{array}{l}\text { PFV Angket } \\
\text { Kepraktisan } \\
\text { dari Guru }\end{array}$ \\
5 & $\begin{array}{l}\text { FV Angket Penilaian } \\
\text { Respon Siswa } \\
\text { PFV Keterlaksanaan }\end{array}$ & $\begin{array}{l}\text { Layak dengan } \\
\text { Revisi } \\
\text { Ladel }\end{array}$ \\
& Layak digunakan \\
\hline
\end{tabular}

meminimalkan kesalahan yang dilakukan ketika siswa praktik mengingat resiko kecelakaan dan kerusakan yang bisa terjadi bisa fatal. Selama proses belajar guru mengobservasi kegiatan praktik kelompok siswa, memberikan umpan balik hasil kerja kelompok, dan pada fase memberikan pengakuan dan penghargaan guru menilai hasil kerja kelompok. Keterlaksanaan prinsip reaksi sebesar $100 \%$ pada semua pertemuan.

Sistem pendukung dan dampak instruksional berupa RPP dan perangkat asesmen, termasuk peralatan mesin bahan praktik dan juga jobsheet. Setiap kelompok siswa mendapatkan bahan, jobsheet (gambar kerja), dan fasilitas mesin beserta kelengkapannya. Karena keterbatasan jumlah mesin frais yang ada, kelompok siswa dengan sabar menunggu giliran untuk melakukan praktik. Setiap kelompok siswa mendapat kesempatan untuk melakukan praktik dalam menyelesaikan proyek berupa balok rumah pahat. Model pembelajaran kooperatif tipe berbagi dikembangkan untuk mencapai tujuan langsung (dampak instruksional) yaitu: peningkatan proses dan aktivitas siswa melalui belajar kelompok, peningkatan penguasaan kompetensi Inti (KI) dan kompetensi dasar (KD) yang ada pada mata pelajaran sebagai hasil belajar siswa. Aktivitas siswa dalam belajar kelompok berinteraksi dengan anggota kelompok, dengan peran dan tanggungjawab yang sama sudah terbentuk dengan baik. Pemahaman anggota kelompok dalam proses belajar terbentuk dari aktivitas diskusi-diskusi yang dilakukan bersama anggota kelompok. Hasil akhir dari kegiatan ini sebagai bukti yang menunjukkan ketercapaian indikator pembelajaran yang dijabarkan dari $\mathrm{KI}$ dan KD mata pelajaran Teknik Pemsinan Frais. Keterlaksanaan sistem pendukung dan dampak instruksional pada pertemuan 1 sampai 3 mencapai $100 \%$.

Hasil penilaian kelayakan dari ahli ditinjau dari aspek petunjuk, isi, dan bahasa pada instrumen penelitian disajikan pada tabel 1 berikut ini.

Tabel 1 Hasil Validasi Kelayakan Instrumen

Analisis data pada instrumen penilaian kevalidan dengan menggunakan formula Gregory didapatkan besarnya koefisien validitas buku model sebesar 1,00 dengan derajat validitas sangat tinggi, koefisien validitas RPP sebesar 1,00 dengan derajat validitas sangat tinggi, dan koefisien validitas asesmen proyek sebesar 1,00 dengan derajat validitas sangat tinggi. Untuk penilaian kepraktisan dari hasil uji coba lapangan dengan angket kepraktisan dari guru secara keseluruhan dari aspek penilaian telah memenuhi kriteria praktis, seperti yang disajikan pada tabel berikut:

Tabel 2 Hasil Penilaian Angket Kepraktisan dari Guru

\begin{tabular}{ccc}
\hline Pertemuan Ke & Skor & Kriteria \\
\hline 1 & 37 & Praktis \\
2 & 43 & Praktis \\
3 & 50 & Sangat Praktis
\end{tabular}

Penilaian kepraktisan dari angket respon siswa terhadap penerapan model pembelajaran diperoleh nilai skor aktual 12.433 dengan kriteria sangat praktis, dan 
persentase jawaban ya dari siswa sebesar $89 \%$.

Berdasarkan hasil penelitian pengembangan model pembelajaran kooperatif tipe berbagi dengan asesmen proyek untuk siswa kelas XI semester I kompetensi keahlian teknik pemesinan di SMK Negeri 3 Singaraja dapat dikatakan sebagai model pembelajaran yang layak untuk digunakan dan memenuhi penilaian kualitas kevalidan dan kepraktisan sebagai suatu model pembelajaran untuk diterapkan.

Penilaian komponen-komponen pengembangan model pembelajaran kooperatif tipe berbagi dengan asesmen proyek yang dihasilkan sesuai dengan harapan peneliti menghasilkan suatu model pembelajaran kooperatif tipe berbagi dengan asesmen proyek. Konsep berbagi mengadopsi dari model kerja sistem subak yang ada di Bali sebagai bagian dari penelitian berbasis budaya lokal. Esensi dari pewarisan nilai-nilai budaya lokal kepada siswa dalam upaya mengenalkan dan menumbuhkan sikap gotong royong, rasa tanggung jawab bersama mulai dari persiapan, proses, dan pelaporan hasil dalam asesmen proyek, sabar dalam menunggu giliran untuk melakukan praktik pengefraisan, sampai pada melakukan kegiatan pembersihan dan pelumasan mesin setelah melakukan praktik secara aktif dilakukan bersama anggota kelompok. Perlakuan adil dan merata kepada setiap anggota kelompok dan peran yang sama (tanpa adanya peran anggota yang mendominasi) menjadi pembeda dalam model pembelajaran kooperatif biasa. Upaya untuk mengimplementasikan budaya gotong royong subak melalui interaksi sosial yang didasari nilai-nilai luhur untuk kebersamaan mampu membentengi pribadi siswa untuk bisa terhindar dari konflik sosial yang sering terjadi sekarang ini. Keselarasan materi pembelajaran dan latar belakang budaya yang dimiliki siswa mampu membentuk pengetahuan siswa dalam proses pembelajaran. Proses pembelajaran melalui pengembangan pengalaman belajar sebagai upaya dalam mengakomodasi aspek kompetensi dan kecakapan hidup terutama aspek akademis dan sosial siswa. Nilai-nilai demokratis, kerjasama, menghargai pluralisme dan mampu belajar aktif yang ada dalam model pembelajaran kooperatif tipe berbagi sejalan dengan paradigma baru pengembangan kurikulum 2013 SMK yaitu : 1) mengembangkan keseimbangan antara pengembangan sikap spiritual dan sosial, rasa ingin tahu, kreativitas, kerja sama dengan kemampuan intelektual dan psikomotorik; 2) sekolah merupakan bagian dari masyarakat yang memberikan pengalaman belajar terencana dimana peserta didik menerapkan apa yang dipelajari di sekolah ke masyarakat dan memanfaatkan masyarakat sebagai sumber belajar; 3) mengembangkan sikap, pengetahuan, dan keterampilan serta menerapkannya dalam berbagai situasi di sekolah dan masyarakat; 4) memberi waktu yang cukup leluasa untuk mengembangkan berbagai sikap, pengetahuan, dan keterampilan.

\section{PENUTUP}

Berdasarkan uraian hasil pengembangan dan pembahasan, maka dalam penelitian pengembangan model pembelajaran kooperatif tipe berbagi dengan asesmen proyek untuk

siswa SMK Kelas XI Semester I Kompetensi Keahlian Teknik Pemesinan di SMK Negeri 3 Singaraja dapat disimpulkan hal-hal sebagai berikut.

1. Komponen model pembelajaran kooperatif tipe berbagi adalah : (a) sintak, yang terdiri dari (1) penyampaian tujuan dan persiapan, (2) menyajikan informasi, mengorganisir siswa dalam tim belajar, (4) diskusi dalam tim memecahkan masalah yang dihadapi, (5) penyampaian hasil, menarik kesimpulan dan melakukan evaluasi, (6) memberikan pengakuan dan penghargaan, (b) Sistem sosial, berupa pembelajaran berkelompok dimana siswa berperan dalam kegiatan belajar berkelompok dan terjadi transfer ilmu melalui interaksi antar anggota dalam kelompok belajar, rasa tanggungjawab 
yang sama dan adil secara merata, tidak ada siswa yang menonjol dalam proses belajar yang membedakan dari pembelajaran kooperatif biasa. Pembelajaran demokratis juga berlangsung melalui kegiatan praktik dimana siswa dengan sabar menunggu kesempatan untuk dapat menggunakan mesin frais, peranan Guru memfasilitasi kegiatan belajar, (c) Prinsip Reaksi dalam pembelajaran guru selain sebagai fasilitator juga berperan sebagai moderator membimbing dan mengevaluasi proses belajar, memberikan umpan balik dan menilai hasil kerja siswa, (d) Sistem pendukung dalam model pembelajaran kooperatif tipe berbagi ini adalah adanya Rencana Pelaksanaan Pembelajaran dan perangkat asesmen proyek, dan dampak instruksional dari penerapan model pembelajaran kooperatif tipe berbagi ini bisa dilihat dari peningkatan proses dan aktivitas siswa melalui belajar kelompok, peningkatan penguasaan kompetensi Inti (KI) dan kompetensi dasar (KD) pada mata pelajaran Teknik Pemsinan Frais. Keterampilan belajar kooperatif dalam kelompok melalui kerjasama guru dan siswa dan siswa dengan anggota kelompoknya, kemampuan mengendalikan diri, menumbuhkan sikap tanggungjawab, dan motivasi siswa dalam belajar kelompok sebagai tujuan tidak langsung dari penerapan model pembelajaran.

2. Penilaian kevalidan model pembelajaran kooperatif tipe berbagi dengan asesmen proyek yang didapatkan adalah: 1) model pembelajaran yang didalamnya menyangkut komponen sintak, sistem sosial, prinsip reaksi, sistem pendukung dan dampak instruksional sudah mencapai hasil dengan kriteria derajat validitas sangat tinggi, 2) perangkat pendukung model pembelajaran RPP dan perangkat asesmen proyek mencapai hasil dengan kriteria derajat validitas sangat tinggi. Penilaian kepraktisan penerapan model pembelajaran kooperatif tipe berbagi melalui angket penilaian kepraktisan di dapatkan hasil : 1) angket guru dengan hasil praktis , 2) angket respon siswa dengan hasil skor aktual 12,433 kriteria sangat praktis.

Berdasarkan hasil penelitian dan pembahasan, dapat diajukan saran bahwa model pembelajaran ini dikembangkan berdasarkan karakteristik siswa SMK Negeri 3 Singaraja Kompetensi Keahlian Teknik Pemesinan, sehingga nantinya bila digunakan pada mata pelajaran atau sekolah lain dan ditemukan kekurangsempurnaan yang perlu diperbaikai, maka disarankan untuk merevisi sesuai kebutuhan, karena keterbatasan waktu dan biaya, pengembangan model pembelajaran ini hanya terbatas pada uji validitas isi dan kepraktisan penerapan model pembelajaran, sehingga disarankan untuk pengembangan selanjutnya bisa dicari keefektifan dari penerapan model pembelajaran ini.

\section{DAFTAR RUJUKAN}

Anita Lie. (2007). Cooperative Learning,Mempraktikan Cooperative Learning di Ruangruang Kelas. Jakarta : Grasindo

Isjoni. (2009). Pembelajaran Kooperatif Meningkatkan Kecerdasan Komunikasi Antar Peserta Didik. Yogyakarta: Pustaka Belajar

Joyce.B., Weil, M., and Shower, B. (1992). Models of Teaching. Massachuestts:Allyn and Bacon.

Joyce, Weil, \& Calhoun, (2009). Model Of Teaching/ Model-model Pembelajaran. Yogyakarta : Sinar Pustaka

Joyce \& Weil. (2009). Models Of Teaching Model-model Pengajaran Edisi kedelapan. Yogyakarta: Pustaka Pelajar 
Pemerintah Republik Indonesia (2003). Undang-undang Republik Indonesia Nomor 20 Tahun 2003, tentang Sistem Pendidikan Nasional.

Saifuddin Azwar. (2010). Tes prestasi. Yogyakarta: Pustaka Pelajar.
Windia W. (2010). Sustainability of subak irrigation system in Bali (experienceof Bali island). Dipresentasikan dalam: Seminar on The History of Irrigation in Eastern Asia; 2010Oktober 13; Yogyakarta, Indonesia. Yogyakarta (ID): ICID.IID 